\title{
Rhizobacteria strains as promoters of rooting in hybrids of Eucalyptus nitens $\times$ Eucalyptus globulus
}

\author{
Paulina González ${ }^{1}$, Katherine Sossa ${ }^{1}$, Francisco Rodríguez ${ }^{2}$, and Eugenio Sanfuentes ${ }^{1 *}$ \\ ${ }^{1}$ Universidad de Concepción, Facultad de Ciencias Forestales, 4070386, Concepción, Chile. \\ *Corresponding author (esanfuen@udec.cl). \\ ${ }^{2}$ Forestal Mininco S.A., Vivero Carlos Douglas, 4580000, Yumbel, Chile.
}

Received: 20 June 2017; Accepted: 13 October 2017; doi:10.4067/S0718-58392018000100003

\section{ABSTRACT}

In Chile, the Eucalyptus nitens (H. Deane \& Maiden) Maiden $\times$ E. globulus Labill. hybrid presents the highest production potential due to its desirable characteristics for the production of cellulose. Nevertheless, its low ability to rooting complicates the clonal propagation in nurseries, with the need for new alternatives to increase rooting. The objective of this research was to evaluate the effect of rhizobacteria in the adventitious rooting of mini-cuttings of two hybrid E. nitens $\times E$. globulus clones, wherein 106 rhizospheric bacterial isolates from five species and hybrids of Eucalyptus spp. were used. The mini-cuttings were treated at the base with a $20 \mathrm{~mL}$ liquid suspension of rhizobacterial strains. In addition, cultured bacteria were applied by manual sprinklers in the rooting substrate. In the first trial, $38 \%$ of rhizobacteria increased significantly rooting of X-64 clone mini-cuttings. Of these, in a second trial, $50 \%$ of rhizobacteria maintained their effect in promoting the rooting in two clones, and in the third trial among the 20 strains evaluated, 10 strains increased rooting in both clones. The rhizobacteria that had the most consistent effect in the rooting increase of the mini-cuttings were species of Bacillus and Pseudomonas sp., as well as the genera Chryseobacterium, Mucilaginibacter and Rhodococcus sp., with these results, it is concluded that 10 rhizobacterial isolates have increased the adventitious rooting of minicuttings of two hybrid clones of E. nitens $\times E$. globulus, and these inoculants could be used in periods of underperformance of minicuttings, in order to optimize their performance.

Key words: Eucalyptus, forestry nurseries, rhizobacteria, roots, hybrids.

\section{INTRODUCTION}

Species derived from the Eucalyptus genus constitute the second most important forestry resource in Chile after Pinus radiata D. Don, approximately covering $34.9 \%$ of the total forest plantations (INFOR, 2016). Its importance is due to its high volumetric yield per area, short fibers and higher wood density, characteristics that are excellent for the production of cellulose (Sotelo and Monza, 2007). Within the Eucalyptus genus species, eucalyptus (Eucalyptus globulus Labill.) is the most planted due to its rapid growth and high pulp quality (Coopman et al., 2008), closely followed by the E. nitens (H. Deane \& Maiden) Maiden that presents a lower surface area, however, exhibits high tolerance to low temperatures and rapid growth rate (Humphreys et al., 2008).

In order to identify superior eucalyptus genotypes that increase the levels of production, traditional improvement programs have explored its genetic variation and hybridization. Among the hybrid genotypes, desired characteristics like rapid growth, wood properties like short fiber, pest resistance and stress tolerance are combined for improving 
plantations productivity (Grattapaglia and Kirst, 2008). From here, the inter-specific hybridization in Eucalyptus has been a low cost and efficient method for improvement programs (Rezende et al., 2014). In Chile, the use of hybrid $E$. nitens $\times$ E. globulus clones has become relevant due to their higher production levels in comparison to its parent species, presenting intermediate characteristics of its technological wood properties, added to resistance to cold environments (Madhibha et al., 2013).

The system for proliferating Eucalyptus has been based on the clonal propagation, which consists of the adventitious rooting of vegetative material using cuttings and mini-cuttings obtained from mother plants (Pardos, 2007). Nevertheless, problems surge with the application of this technique due to the variability in the rooting capacity among the species and hybrid clones, frequently causing a gradual reduction in the rooting potential (Teixeira et al., 2007). The situation in Chile follows this tendency mostly in hybrid clones of Eucalyptus, such as the E. nitens $\times$ E. globulus hybrid, which presents reductions in rooting (Díaz et al., 2009).

The adventitious rooting is affected by multiple endogenous and exogenous factors. Specific factors of the plant include the juvenility, cutting diameter, presence of buds or leaves, the species and nutritional state of the plant. On the other hand, endogenous factors such as phytohormones, phenolic compounds, and genetic characteristics of the plant also influence rooting (Da Costa et al., 2013). The environmental conditions that also can affect the physiological process are the collection period of the cutting, humidity, temperature, luminosity, photoperiod, chemical composition of the substrate, stress, and microorganisms mainly mycorrhizal fungi and bacteria (Bellini et al., 2014) present in the soil and/or substrate of the rooting (Dennis et al., 2010).

The constant problems in the adventitious rooting of the elite material for the Eucalyptus spp., have intensified the search for methods that increase rooting. In this scenario, rhizobacteria has appearing as a promising strategy due to its characteristics that allow the increment of rooting and growth rate, in addition to the possibility of acting as biological control agents (Ahemad and Kibret, 2014) against phytopathogens like Rhizoctonia solani, Xanthomonas oryzae (Bhattachryya and Jha, 2012) and Botrytis cinerea one of the main pathogens of Eucalyptus sp. (Trotel-Aziz et al., 2008). The potential of the rhizobacteria has been demonstrated principally in agricultural crops, where have been registered increment in the length and biomass of roots, as well as improvements in germination rate and crop production, among others (Babalola, 2010). On the other hand in forestry the species rhizobacteria research is limited, however, it has been demonstrated that rhizobacteria have increased the biomass and plant height for the species Pinus, Quercus, Picea and Pseudotsuga menziesii (Mirb.) Franco and Eucalyptus camaldulensis Dehnh. (Mafia et al., 2007; Teixeira et al., 2007; Karthikeyan and Sakthivel, 2011; Gumiere et al., 2014). In addition, for the Eucalyptus grandis W. Hill ex Maiden and E. globulus cuttings, through the application of Bacillus spp., and Pseudomonas spp., has been possible to increase the rooting and biomass of these species (Teixeira et al., 2007; Díaz et al., 2009). On the other the use of Azotobacter chroococcum for the E. camaldulensis have presented increment on biomass, and roots number and length (Karthikeyan and Sakthivel, 2011).

For these reasons and considering the potential benefit of the bacteria in the production of eucalyptus plants, the objective of this paper was to evaluate the effect of rhizobacteria, in the rooting of mini-cuttings of two hybrid clones of E. nitens $\times$ E. globulus.

\section{MATERIALS AND METHODS}

\section{Isolation of the rhizobacteria}

The rhizobacteria isolation was carried out according to the methodology described by Angulo et al. (2014), in which the strains were obtained from the rhizosphere of five clones of Eucalyptus: two hybrids of E. nitens $\times E$. globulus (X-64, X-65), two clones of E. globulus (X-49 and X-52) and one clone of the hybrid E. globulus $\times$ E. camaldulensis Dehnh. (X-89). For the isolation process, four selective culture media were utilized: casein yeast (CCY) for the Bacillus spp., King B (KB) for the Pseudomonas spp., starch casein (AC) for the Streptomyces spp. and finally the Rasoner's 2A (R2A agar) as a general isolation medium.

During this procedure, the Petri dishes with bacterial growth were conserved at $25^{\circ} \mathrm{C}$ for $4 \mathrm{~d}$, and later the rhizobacteria samples were selected in terms of color and morphology of its colonies. Finally, the chosen strains were stored in a mixture of liquid medium (R2A broth) and glycerol (70\%) at $-80{ }^{\circ} \mathrm{C}$ for their future use during the rooting trials. 


\section{Rooting trials}

Three trials were conducted. The first was in January 2011 (Trial 1), the second in October 2011 (Trial 2) and the third in January 2012 (Trial 3), which coincides with the summer season for the clonal propagation of the Eucalyptus species in Chile. The trials location was in the Los Ángeles Forestry Nursery, owned by Forestal Mininco S.A., Los Ángeles.

During Trial 1 only the hybrid X-64 (E. nitens $\times$ E. globulus) clone was used and for Trials 2 and 3 the hybrid clones X-64 and X-65 (all with low rooting) were utilized. Additionally in Trials 1 and 2 second order mini-cuttings were used, which is obtained for the middle part of the mother plant, this imply that they have no apex and present approximately $5 \mathrm{~cm}$ length. On the other hand, in Trial 3, $7 \mathrm{~cm}$ length apical mini-cuttings were obtained from the apexes of the mother plants.

For the production of the rhizobacteria inoculum, the strains were cultivated using R2A liquid medium during 48 $\mathrm{h}$ at $25^{\circ} \mathrm{C}$ and shaken at $120 \mathrm{rpm}$, until a concentration of $1 \times 10^{8}$ colony-forming units $(\mathrm{CFU}) \mathrm{mL}^{-1}$ was reached. In addition, $120 \mathrm{~mL}$ cultured bacteria were applied by manual sprinklers in 1 L rooting substrate, which was composed by a mixture of turf, vermiculite and perlite in proportion $50 \%-30 \%-20 \%$, respectively. The inoculated substrate was introduced in plastic bags for the incubation stage at $25^{\circ} \mathrm{C}$ during $48 \mathrm{~h}$. At the forestry nursery, the collected mini-cuttings were treated through immersion for $10 \mathrm{~s}$ in bacterial suspension $\left(1 \times 10^{8} \mathrm{CFU} \mathrm{mL}^{-1}\right)$. Immediately, the mini-cuttings were planted in individual rooting trays (241 cavities), wherein each cavity contained $15.5 \mathrm{~mL}$ previously treated substrate together with the rhizobacterial strains.

\section{Evaluation and experimental design}

The trials used a randomized block design, wherein were considered three blocks in Trials 1 and 2, and four blocks in Trial 3. Firstly, Trial one was arranged in 107 treatments corresponding to 106 rhizobacterial strains and one control (water), wherein the experimental unit included 10 mini-cuttings. Later in Trial 2, the 32 strains that had best rooting effects in Trial 1 were chosen, adding one control (water) and a 20 mini-cuttings experimental unit. In Trial 3, the 20 strains with best rooting effects in Trial 2 were chosen, wherein were added one control (water) and 20 mini-cuttings experimental units. During the trials, hormones were not used and the RH was maintained at $80 \%$ for the first $7 \mathrm{~d}$, after this period, $\mathrm{RH}$ was decreased at $70 \%$. After $45 \mathrm{~d}$ of each trial's set up, percentage of rooted mini-cuttings, length $(\mathrm{cm})$ and root biomass (dry weight, $\mathrm{mg}$ ) were evaluated. The results were analyzed with the software SAS 9.2. (SAS Institute, Cary, North Carolina, USA), comparing the means to establish $\mathrm{p}<0.05$ significant differences with the Fisher test.

\section{Identification of the rhizobacteria}

The rhizobacteria that had the greatest effect on the rooting of the mini-cuttings was identified through the amplification of the $16 \mathrm{~S}$ rDNA, using the methodology of Jopia et al. (2011) with modifications. The polymerase chain reaction (PCR) was used in order to obtain the segment of amplified DNA with the specific primers $9 \mathrm{f}$ and 1492r, with the following sequence; 9f 5'-GAG TTT GAT CCT GGC TCA G-3' y 1492r 5'-GGY TAC CCT GTT ACG ACTT-3'. In addition, the mix used in the reaction was $25 \mu \mathrm{L}$ with: $1 \mu \mathrm{L}$ genomic DNA, $1 X$ Flexi buffer

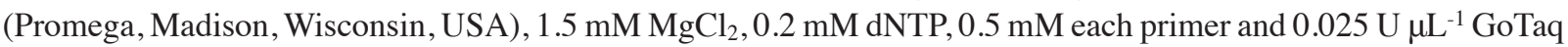
polymerase (Promega). The amplification process was performed in a Thermocycler (Mastercycler Gradient PCR Thermal Cycler, Model 5331, EEppendorf, Hamburg, Germany). The cycle and the PCR temperature programs were the following: a) one cycle of $2 \mathrm{~min}$ at $95^{\circ} \mathrm{C}$; b) 30 cycles configured in three segments; first segment $30 \mathrm{~s}$ at $95^{\circ} \mathrm{C}$, second segment $30 \mathrm{~s}$ at $94^{\circ} \mathrm{C}$, and third segment $1 \mathrm{~min} 30 \mathrm{~s}$ at $72{ }^{\circ} \mathrm{C}$; then c) one cycle of 2 min at $72{ }^{\circ} \mathrm{C}$ maintaining the final PCR product at $4{ }^{\circ} \mathrm{C}$. The amplification of the DNA segment was verified by electrophoresis in agarose gel $(1.5 \%)$, staining the gel with ethidium bromide $\left(0.5 \mu \mathrm{g} \mathrm{mL}^{-1}\right)$. The PCR product was sent to Macrogen (Seoul, South Korea) for its sequencing, and the sequences were edited with the software GENEIUS and inserted into the National Center for Biotechnology Information database (NCBI, US National Library of Medicine, Bethesda Maryland, USA) for the rhizobacterial strains identification. Afterwards, a complementary identification was developed in order to prove the identity of the strains in which were used the pair of specific cry $8 \mathrm{f}$ and cry $8 \mathrm{r}$ primers of Bacillus thuringiensis (Chen et al., 2014) in a new PCR. The PCR conditions were the same as those previously used with 
modification in the temperature program as follows: One cycle of $3 \mathrm{~min}$ at $94{ }^{\circ} \mathrm{C} ; 35$ cycles consisting of three segments; first segment $30 \mathrm{~s}$ at $94{ }^{\circ} \mathrm{C}$, second segment $40 \mathrm{~s}$ at $55^{\circ} \mathrm{C}$, and third segment from 1 to $72{ }^{\circ} \mathrm{C}$; then one cycle of 5 min at $72{ }^{\circ} \mathrm{C}$ maintaining the final PCR product at $4{ }^{\circ} \mathrm{C}$.

\section{RESULTS}

\section{Trial 1}

Among the 106 rhizobacterial strains, 84 strains were evaluated, due to the high mortality in the mini-cuttings of 22 strains, associated to watering problems in some specific sectors within the greenhouse. Over the 84 strains, 32 were significantly increased their rooting of the X-64 clone (Table 1), presenting a rooting efficiency between $32 \%$ and $75 \%$, wherein the strain 53 has triplicate the control rooting of $28 \%$. Additionally, an average gain of $73 \%$ is reached among the 32 strains. Moreover, it is important to mention that within the treatments that affected the rooting, $31 \%$ were rhizosphere strains of the X-64 clone, indicating correlation between the clone and bacterial strain.

\section{Trial 2}

Among the 32 rhizobacterial strains that increased rooting of the E. nitens $\times$ E. globulus (X-64) clone mini-cuttings in the previous trial, and which were evaluated in this trial, nine rhizobacterial strains had the capacity to significantly increase rooting in the X-64 clone mini-cuttings, presenting a fluctuation between $9 \%$ and $18 \%$. Additionally, other seven strains had an effect on the X-65 clone, with a rooting increase between 36 - 41\% (Table 2). Furthermore, in this trial the control rooting for the X-64 clone was very low (1\%), added to six strains that increased the length of the root in the X-64 clone, with no observable effect in roots for the X-65 clone. Finally, in the X-64 clone, three rhizobacterial strains $\left(\mathrm{N}^{\circ} 122, \mathrm{~N}^{\circ} 43\right.$ and $\left.\mathrm{N}^{\circ} 59\right)$ have presented changes in both rooting and root length.

Table 1. Rooting of Eucalyptus nitens $\times$ E. globulus (clone X-64) mini-cuttings, treated with different rhizobacterial strains and control (Trial 1).

\begin{tabular}{|c|c|c|c|c|c|}
\hline $\begin{array}{l}\text { Strain } \\
\text { (clone origin) }\end{array}$ & $\begin{array}{c}\text { Rooting } \\
(\%)\end{array}$ & $\begin{array}{c}\text { Strain } \\
\text { (clone origin) }\end{array}$ & $\begin{array}{c}\text { Rooting } \\
(\%)\end{array}$ & $\begin{array}{c}\text { Strain } \\
\text { (clone origin) }\end{array}$ & $\begin{array}{c}\text { Rooting } \\
(\%)\end{array}$ \\
\hline Control & 28 & $20(X-64)$ & $38^{*}$ & $41(X-64)$ & 28 \\
\hline $53(X-89)$ & $75^{*}$ & $13(X-64)$ & $38 *$ & $31(\mathrm{X}-49)$ & 27 \\
\hline $21(X-64)$ & $63^{*}$ & $56(X-65)$ & $37 *$ & $24(X-52)$ & 26 \\
\hline $44(X-49)$ & $63^{*}$ & $119(\mathrm{X}-49)$ & $37 *$ & $125(\mathrm{X}-52)$ & 25 \\
\hline $89(X-89)$ & $60 *$ & $59(X-64)$ & $37 *$ & $105(X-89)$ & 25 \\
\hline $92(X-49)$ & $58^{*}$ & $122(\mathrm{X}-52)$ & $37 *$ & $27(X-49)$ & 24 \\
\hline $106(X-49)$ & $58^{*}$ & $72(X-65)$ & 35 & $61(X-89)$ & 24 \\
\hline $52(\mathrm{X}-89)$ & $58 *$ & $51(\mathrm{X}-89)$ & 35 & $33(\mathrm{X}-49)$ & 23 \\
\hline $14(X-49)$ & $57 *$ & $34(X-65)$ & 35 & $114(\mathrm{X}-89)$ & 23 \\
\hline $87(\mathrm{X}-65)$ & $56^{*}$ & $35(X-64)$ & 33 & $118(\mathrm{X}-64)$ & 23 \\
\hline $121(\mathrm{X}-64)$ & $56^{*}$ & $91(\mathrm{X}-89)$ & 33 & $103(X-64)$ & 23 \\
\hline $46(X-65)$ & $56^{*}$ & $3(X-64)$ & 33 & $74(X-52)$ & 22 \\
\hline $63(X-65)$ & $53^{*}$ & $55(X-64)$ & 33 & $104(X-64)$ & 22 \\
\hline $58(\mathrm{X}-65)$ & $52 *$ & $60(X-64)$ & 33 & $124(\mathrm{X}-52)$ & 22 \\
\hline $86(X-89)$ & $51 *$ & $77(X-49)$ & 32 & $12(X-64)$ & 21 \\
\hline $18(\mathrm{X}-64)$ & $47 *$ & $83(X-64)$ & 32 & $117(\mathrm{X}-89)$ & 20 \\
\hline $49(X-49)$ & $46^{*}$ & $1(\mathrm{X}-52)$ & 32 & $8(\mathrm{X}-65)$ & 20 \\
\hline $62(X-49)$ & $46^{*}$ & $45(X-65)$ & 31 & $109(X-165)$ & 19 \\
\hline $75(X-52)$ & $44^{*}$ & $67(X-89)$ & 31 & $100(X-52)$ & 19 \\
\hline $17(\mathrm{X}-65)$ & $44 *$ & $25(X-89)$ & 30 & $23(X-52)$ & 18 \\
\hline $69(X-64)$ & $44^{*}$ & $16(\mathrm{X}-52)$ & 30 & $4(X-64)$ & 18 \\
\hline $43(X-49)$ & $43^{*}$ & $68(X-52)$ & 29 & $28(X-65)$ & 17 \\
\hline $54(\mathrm{X}-89)$ & $43^{*}$ & $123(\mathrm{X}-52)$ & 29 & $22(X-64)$ & 13 \\
\hline $48(\mathrm{X}-65)$ & $43^{*}$ & $95(X-52)$ & 29 & $112(\mathrm{X}-89)$ & 10 \\
\hline $81(\mathrm{X}-64)$ & $42 *$ & $102(\mathrm{X}-65)$ & 28 & $11(\mathrm{X}-64)$ & 7 \\
\hline $84(\mathrm{X}-64)$ & $41^{*}$ & $65(X-64)$ & 28 & $64(X-65)$ & 6 \\
\hline $116(X-52)$ & $40 *$ & $29(X-64)$ & 28 & $79(X-49)$ & 5 \\
\hline $66(X-64)$ & $40 *$ & $7(X-52)$ & 28 & $37(X-64)$ & 4 \\
\hline
\end{tabular}

*Strains that presented rooting (\%) significantly greater than control. 
Table 2. Rooting and root length in the Eucalyptus nitens $\times$ E. globulus X-64 and X-65 clones mini-cuttings treated with different rhizobacterial strains (Trial 2).

\begin{tabular}{|c|c|c|c|c|}
\hline \multirow[b]{2}{*}{ Strain } & \multicolumn{2}{|c|}{ Rooting } & \multicolumn{2}{|c|}{ Root length } \\
\hline & X-64 & X-65 & X-64 & $X-65$ \\
\hline & 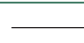 & 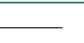 & 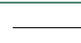 & $\bar{z}$ \\
\hline Control & 1 & 26 & 0.1 & 4.3 \\
\hline 122 & $18^{\dagger}$ & $36^{\dagger}$ & $3.1^{*}$ & 4.0 \\
\hline 43 & $17^{\dagger}$ & $38^{\dagger}$ & $4.0^{\ddagger}$ & 4.4 \\
\hline 59 & $14^{\dagger}$ & 24 & $3.3^{\ddagger}$ & 3.4 \\
\hline 87 & $10^{\dagger}$ & 28 & 1.4 & 5.0 \\
\hline 14 & $9^{\dagger}$ & 28 & 1.5 & 3.9 \\
\hline 63 & $9^{\dagger}$ & 29 & 1.5 & 3.9 \\
\hline 86 & $9^{\dagger}$ & $36^{\dagger}$ & 1.0 & 5.0 \\
\hline 20 & $9^{\dagger}$ & 30 & 1.2 & 5.2 \\
\hline 119 & $9^{\dagger}$ & $39^{\dagger}$ & 1.6 & 4.1 \\
\hline 21 & 8 & 24 & 1.6 & 4.4 \\
\hline 89 & 8 & 16 & $1.8^{\ddagger}$ & 3.9 \\
\hline 92 & 8 & 20 & 1.4 & 3.5 \\
\hline 44 & 6 & $41^{\dagger}$ & $2.6^{\ddagger}$ & 4.0 \\
\hline 121 & 6 & $40^{\dagger}$ & 1.7 & 5.1 \\
\hline 53 & 5 & 31 & 0.5 & 4.3 \\
\hline 106 & 5 & 19 & 0.9 & 4.2 \\
\hline 17 & 5 & 24 & 0.5 & 4.2 \\
\hline 116 & 5 & 30 & 1.0 & 2.5 \\
\hline 51 & 5 & 35 & 1.6 & 3.6 \\
\hline 55 & 5 & 15 & 0.7 & 2.4 \\
\hline 69 & 4 & 30 & $2.3^{\ddagger}$ & 3.7 \\
\hline 54 & 4 & 19 & 1.6 & 3.1 \\
\hline 81 & 4 & 18 & 1.7 & 5.6 \\
\hline 46 & 3 & 35 & 0.6 & 5.1 \\
\hline 7 & 3 & 25 & 0.4 & 3.2 \\
\hline 18 & 3 & 21 & 1.2 & 2.0 \\
\hline 48 & 3 & 30 & 1.2 & 4.2 \\
\hline 56 & 3 & 20 & 0.9 & 3.6 \\
\hline 34 & 1 & 35 & 0.9 & 3.7 \\
\hline 58 & 1 & 33 & 0.1 & 4.4 \\
\hline 49 & 1 & $40^{\dagger}$ & 0.3 & 4.0 \\
\hline
\end{tabular}

Strains with significant differences $(\mathrm{p}<0.05)$ compared to the rooting control.

*Strains with significant differences $(\mathrm{p}<0.05)$ compared to the root length control.

\section{Trial 3}

In this trial, 20 rhizobacterial strains have initially tested, where the chosen selection criterion was the highest levels of rooting achieved in the previous trials. Twelve strains have increased their rooting for the E. nitens $\times$ E. globulus X-64 clone mini-cuttings, presenting an average gain of 77\% (Table 3). Otherwise, for the E. nitens $\times$ E. globulus X-65 clone, 10 strains have increased the rooting with an average gain of 27\%. Additionally, in this trial, 10 strains presented increased rooting in both clones. The rhizobacteria did not have effect on the root length (Table 3 ) nor in the biomass for both clones' mini-cuttings.

At the end of these three nursery trials, 10 bacterial strains that obtained the best results in rooting for the $E$. nitens $\times$ E. globulus X-64 and X-65 clones mini-cuttings were identified, through the sequencing of 16s rDNA. Additionally, through the comparison of the sequences obtained with the NCBI database, five strains have been identified at the genus level, and two at the species level corresponding to Bacillus thuringiensis (Table 4). This identification was completed using the cry 8 gene, that encodes the specific toxin Cry produced by this species of bacteria. The gel electrophoresis shows the amplification of the gene proving its presence in the strains 63 and 122 , identified both as B. thuringiensis (Figure 1). 
Table 3. Effect of rhizobacterial strains in rooting and root length in the Eucalyptus nitens $\times$ E. globulus X-64 and X-65 clones and control (Trial 3).

\begin{tabular}{|c|c|c|c|c|}
\hline \multirow[b]{2}{*}{ Strain } & \multicolumn{2}{|c|}{ Rooting } & \multicolumn{2}{|c|}{ Root length } \\
\hline & X-64 & $X-65$ & X-64 & $X-65$ \\
\hline & 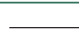 & - & - & - \\
\hline Control & 7 & 54 & 4.5 & 7.0 \\
\hline 119 & $40^{\dagger}$ & $77^{\dagger}$ & 6.0 & 7.0 \\
\hline 18 & $37^{\dagger}$ & $86^{\dagger}$ & 5.7 & 7.4 \\
\hline 92 & $34^{\dagger}$ & 67 & 5.9 & 7.4 \\
\hline 63 & $32^{\dagger}$ & $79^{\dagger}$ & 5.4 & 7.3 \\
\hline 86 & $32^{\dagger}$ & $77^{\dagger}$ & 5.3 & 7.3 \\
\hline 14 & $29^{\dagger}$ & $74^{\dagger}$ & 6.5 & 7.8 \\
\hline 116 & $29^{\dagger}$ & 68 & 7.0 & 7.1 \\
\hline 46 & $28^{\dagger}$ & $74^{\dagger}$ & 6.1 & 7.2 \\
\hline 49 & $28^{\dagger}$ & $78^{\dagger}$ & 6.1 & 7.5 \\
\hline 56 & $27^{\dagger}$ & 67 & 6.1 & 7.7 \\
\hline 59 & $27^{\dagger}$ & 68 & 5.5 & 6.9 \\
\hline 121 & $26^{\dagger}$ & $75^{\dagger}$ & 5.5 & 6.9 \\
\hline 43 & $25^{\dagger}$ & $78^{\dagger}$ & 4.8 & 6.5 \\
\hline 87 & 24 & 61 & 5.9 & 7.4 \\
\hline 122 & 24 & $74^{\dagger}$ & 4.9 & 7.6 \\
\hline 20 & 23 & 57 & 5.4 & 7.4 \\
\hline 52 & 22 & 58 & 6.1 & 6.7 \\
\hline 51 & 21 & 64 & 5.3 & 7.6 \\
\hline 44 & 19 & 62 & 5.0 & 7.4 \\
\hline
\end{tabular}

Strains that presented significant differences compared to the control strain.

Table 4. Identification of rhizobacterial strains that increased the rooting of Eucalyptus nitens $\times$ E. globulus X-64 and X-65 clone mini-cuttings.

\begin{tabular}{rll}
\hline Strain & Identification of similarity (\%) & Number of NCBI accession \\
\hline 92 & Rhodococcus sp. (100) & EU977670.1 \\
14 & Pseudomonas sp. (100) & KT825815.1 \\
121 & Rhodococcus sp. (100) & JQ396589.1 \\
63 & Bacillus thuringiensis $(100)$ & CP015250.1 \\
18 & Bacillus sp. (100) & JN215507.1 \\
49 & Bacillus sp. (100) & NR_042083.1 \\
116 & Rhodococcus sp. (100) & EU977670.1 \\
56 & Mucilaginibacter sp. (100) & NR_042642.1 \\
59 & Chryseobacterium sp. (100) & CP015250.1 \\
119 & Bacillus sp. (100) & KT340481.1 \\
122 & Bacillus thuringiensis $(100)$ & Cen
\end{tabular}

(\%) Percentage of similarity with sequences in National Center for Biotechnology Information (NCBI) database.

\section{DISCUSSION}

Decades ago, bacteria were being researched in order to establish their ability for increasing growth rates in plants, principally for its application in agricultural crops (Adesemoye et al., 2009; Bhattacharyya and Jha, 2012). In particular, the interest for these bacterial inoculums has emerged from the necessity of improve the quantity and quality of the forestry plant production, applying techniques that are more environmentally friendly at a lower cost (Akhtar et al., 2009).

The effect of bacterial inoculums has been verified in conifer seedlings of the genera Pinus, evaluating its effect in the increase of the germination rate, height and dry weight of the seedlings (Puente et al., 2010). Due to the importance of the forestry industry in countries such as Brazil and Chile, studies about the effect of bacteria in Eucalyptus has reached high relevance (Pardos, 2007; Ferreira et al., 2008). One example of this is the research conducted by Díaz et al. (2009), which verified the effect of rhizobacteria in the rooting and root fibrosity. 
Figure 1. Agarose gel from the PCR product using the specific primer of Bacillus thuringiensis cry8. At the top of the gel, the number 1 indicates the lane with the marker of molecular weight $10000 \mathrm{bp}$. At the bottom of the gel, the number 1 indicates the lane with the marker of molecular weight $100 \mathrm{bp}$. The presence of the cry 8 gene is observed in isolate 63 in lanes $2,3,4,5,6$ and in isolate 122 in lanes 7,9, 10 and 11.

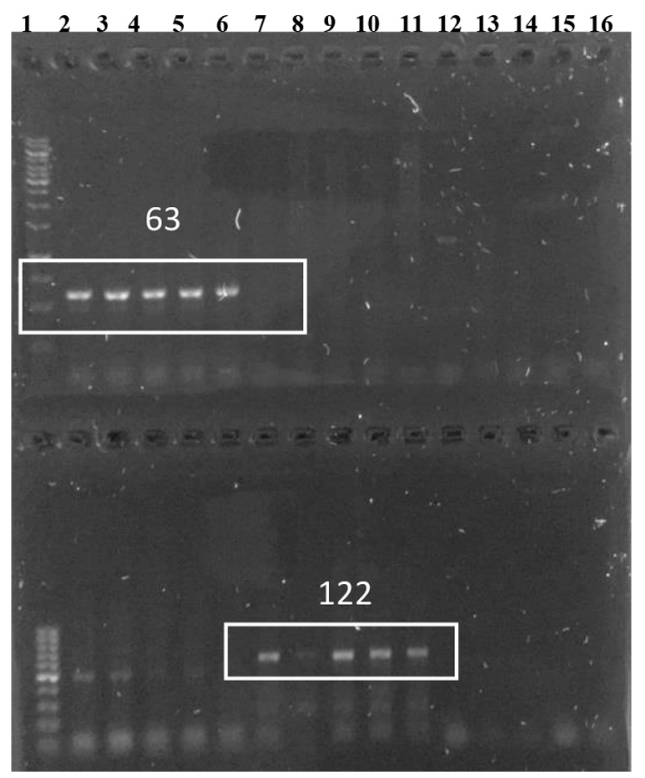

In the present study, rhizobacterial strains have been evaluated in sequential trials in an operational nursery. In the first trial, the average gain in the rooting was $70 \%$, results that are similar to those obtained by Teixeira et al. (2007), which presents an average gain of 63\% in the cuttings of E. grandis hybrid clone, through the application of rhizobacteria strains, principally Bacillus subtilis and Pseudomonas sp. Additionally, Mafia et al. (2007) also obtained gains between $5 \%$ and $90 \%$ in the rooting percentage in Eucalyptus seedlings with different clonal propagation conditions, using in their research strains of Pseudomonas sp., Bacillus sp., and Stenotrophomonas maltophilia. Moreover, Díaz et al. (2009) also analyzed the potential use of rhizobacteria in order to stimulate the rooting in $E$. globulus mini-cuttings, reaching average gains of $41 \%$ through the application of B. subtilis/amyloliquefaciens and B. mycoides. On the other hand the research carried out by Raasch et al. (2013) also verified the effects the B. subtilis rhizobacteria in the hybrid clones E. camaldulensis $\times$ E. grandis and E. urophylla $\times$ E. grandis, with a significant increase in the number of roots emerged from the rooting cavity with maximum of $53.2 \%$.

The increase in the percentage of rooting of these minicuttings, means an increase in the survival of the seedlings that later will be adult trees in the plantations. Therefore, improvement in the first instance of rooting through a biotechnological technique is a valuable tool for the forestry industry. Further, in this first trial, most of the strains with rooting effect (31\%) were strains from the X-64 clone, demonstrating the specificity of the plant-rhizobacteria. This can be principally explained by the nature of the root exudates, which varies according to the genotype of the plant, influencing the type of bacteria that colonize the rhizosphere (Bais et al., 2006). In addition, the characteristic pointed out in this trial have been observed in other studies, for example Mafia et al. (2009), wherein they obtained that the use of isolates from this type of plant have improve in rooting.

In the second trial, the average gains in the rooting was even greater compared to the first trial, with $88 \%$ and $48 \%$ for the E. nitens $\times$ E. globulus X-64 and X-65 clones, respectively. In the case of the X-64 clone, the main effect of the rhizobacteria is partly explained due to the level of rooting is lower at the beginning of the rooting season (October for trial 2) compared to rooting in the full harvest season of mini-cuttings, presenting variations between $28 \%$ and $1 \%$, respectively. Furthermore, the X-64 clone originally possesses a lower natural rooting ability, variability that is frequently mentioned between species and Eucalyptus clones (Teixeira et al., 2007). On the other hand, the factors that influence the formation of the new root such as the development of the mother plant, plant 
nutrition, its metabolites and the environmental conditions, should be considered (Geiss et al., 2009). In particular in Chile, the end of spring and summer is the season in which the highest levels of rooting are obtained, being, nevertheless, lower at the beginning and end of the seasons, due to that the temperature is a relevant factor in the adventitious rooting (Trueman et al., 2013). In the case of this study, it was observed that the largest magnitude in the increase of rooting, occurred in times of lower temperature, and that are more stressful for plants. This behavior is mentioned in previous researches, which indicated that the greatest effect of rhizobacteria on growth tends to be in more stressful conditions for plants (Dimkpa et al., 2009; Ali et al., 2014). Thus the application of these rhizobacteria should be performed at these times and in order to obtain greater effects on rooting.

Additionally in the second trial, six rhizobacteria increased the root length in the X-64 clone mini-cuttings. These results are similar to those observed by Karthikeyan and Sakthivel (2011), wherein the increase of the root length observed in the E. camaldulensis cuttings occurred when Azotobacter chroococcum is applied. Raasch et al. (2013) also observed the increase root length in the hybrid E. urophylla $\times$ E. grandis when inoculating the mini-cuttings and the rooting substrate with the formulation composed of $B$. subtilis.

In the third trial, a greater increase occurred in the rooting of the two clones used due to the employment of apical mini-cuttings, having that the 12 and 10 rhizobacterial strains have significantly increased their rooting in the X-64 and X-65 clones, respectively, presenting average gains of 300\% for the X-64 clone, and $43 \%$ for the X-65 clone. In particular, in this trial the rhizobacteria did not affect the root length, similar situation pointed out by Probanza et al. (2002), who obtained increases in P. taeda and P. pinea seedlings without observable rhizobacterial effects in the root length. As a global result, in the three trials completed the magnitude in the rooting increase was always greater in the X-64 clone compared to the X-65 clone. This can be explained due to the X-64 clone possesses less rooting, which can increase the effect of the rhizobacteria in mini-cuttings that present higher difficulty to root. With this, it is confirmed that the application of the inoculants of rhizobacteria would have greater effect in the minicuttings subjected to some type of stress, that can belong to the plant itself or some environmental stress.

Another point to discuss is related to that 10 rhizobacteria had greater consistency and gains in the rooting in both eucalyptus hybrid clones (Table 3), wherein have been identified species of Bacillus and Pseudomonas, which are known for being Plant growth-promoting rhizobacteria (PGPR) in different plant species (Santoyo et al., 2012). The rhizobacterial strains 63 and 122 correspond to $B$. thuringiensis species, which possess an effect of growth promoter in plants (Armada et al., 2016), likewise a species of the genus Rhodococcus that has been identified, with antecedents of its use as bacterial inocula, promoting the elongation of the plant roots of Brassica juncea (Qaisrani et al., 2014). Moreover, Mucilaginibacter sp. (strain 56) has been found in the rhizosphere of plants (Kim et al., 2012) and lichens, showing increments in the plant growth and being considered PGPR (Madhaiyan et al., 2010). In Chile, the presence of Bacillus and Pseudomonas has been described in previous studies of the rhizosphere of eucalyptus (Díaz et al., 2009); however, it is the first time that other genera such as Rhodococcus and Mucilaginibacter have been described promoting the adventitious rooting of Eucalyptus minicuttings for commercial use. Although this research studies the effect rhizobacteria on adventitious rooting, new trials should be performed in order to determine the mechanisms used by rhizobacteria to increase rooting in vegetative material, like as growing regulators, enzymes modulators or another use.

\section{CONCLUSIONS}

Considering the effect of some rhizobacteria in the nursery trials, in operational conditions of clonal propagation, it is possible to conclude that 10 isolates have increased the adventitious rooting in mini-cuttings of two hybrid clones of Eucalyptus nitens $\times$ E. globulus. However, even though an increase in the length of the root was observed in some strains, there is not strong evidence in order to conclude that there is a rhizobacteria effect on this variable.

In view of the results of this research, 10 rhizobacterial isolates have increased the adventitious rooting of minicuttings of two hybrid clones of E. nitens $\times$ E. globulus under operational conditions of clonal propagation. For this reason, these inoculants could be used in the times of underperformance of minicuttings, in order to optimize their results. Field results should be complemented with laboratory tests to determine which mechanisms would be used for the rhizobacteria for promoting the rooting in minicuttings. These findings not only contribute to scientific 
knowledge, but also represent a relevant contribution for the forestry industry, due to it would improve the production by the use of biotechnological tools, converting the forestry industry into a more sustainable industry.

\section{ACKNOWLEDGEMENTS}

This work and the student were supported by Comisión Nacional de Investigación Científica y Tecnológica (CONICYT).

\section{REFERENCES}

Adesemoye, A., Tobert, H., and Kloepper, J. 2009. Plant growth-promoting rhizobacteria allow reduced application rates of chemical fertilizers. Microbial Ecology 58:921-929. doi:10.1007/s00248-009-9531-y.

Ahemad, M., and Kibret, M. 2014. Mechanisms and applications of plant growth promoting rhizobacteria: Current perspective. Journal of King Saud University-Science 26:1-20. doi:10.1016/j.jksus.2013.05.001.

Akhtar, M.J., Asghar, H.N., Shahzad, K., and Arshad, M. 2009. Role of plant growth promoting rhizobacteria applied in combination with compost and mineral fertilizers to improve growth and yield of wheat (Triticum aestivum L.) Pakistan Journal of Botany 41:381-390.

Ali, S., Trevor, C., and Glick, B. 2014. Amelioration of high salinity stress damage by plant growth-promoting bacterial endophytes that contain ACC deaminase. Plant Physiology and Biochemistry 80:160-167. doi:10.1016/j. plaphy.2014.04.003.

Angulo, V., Sanfuentes, E., Rodríguez, F., y Sossa, K. 2014. Caracterización de rizobacterias promotoras de crecimiento en plántulas de Eucalyptus nitens. Revista Argentina de Microbiología 46:338-347. https://doi.org/10.1016/S03257541(14)70093-8.

Armada, E., Probanza, A., Roldan, A., and Azcon, R. 2016. Native plant growth promoting bacteria Bacillus thuringiensis and mixed or individual mycorrhizal species improved drought tolerance and oxidative metabolism in Lavandula denata plants. Journal of Plant Physiology 192:1-12. doi:10.1016/j.jplph.2015.11.007.

Bais, H., Weir, T., Perry, L., Gilroy, S., and Vivanco, J. 2006. The role of root exudates in rhizosphere interactions with plants and other organisms. Annual Review of Plant Biology 57:233-266. doi:10.1146/annurev.arplant.57.032905.105159.

Babalola, O. 2010. Beneficial bacteria of agricultural importance. Biotechnology Letters 32:1559-1570. doi:10.1007/ s10529-010-0347-0.

Bellini, C., Pacurar, D.I., and Perrone, I. 2014. Adventitious roots and lateral roots: Similarities and differences. Annual Review of Plant Biology 65:639-666. doi:10.1146/annurev-arplant-050213-035645.

Bhattacharyya, P., and Jha, D. 2012. Plant growth-promoting rhizobacteria (PGPR): Emergence in agriculture. World Journal of Microbiology and Biotechnology 28:1327-1350. doi:10.1007/s11274-011-0979-9.

Chen, M., Chen, P., Pang, J., Lin, C., Hwang, C., and Tsen, H. 2014. The correlation of the presence and expression levels of cry genes with the insecticidal activities against Plutella xylostella for Bacillus thuringiensis strains. Toxins 6:24532470. doi:10.3390/toxins6082453.

Coopman, J., Jara, J., Bravo, L., Saez, K., Mella, G., and Escobar, R. 2008. Changes in morpho-physiological attributes of Eucalyptus globulus plants in response to different drought hardening treatments. Electronic Journal of Biotechnology 11:30-39. doi:10.2225/vol11-issue2-fulltext-9.

Da Costa, C.T., De Almeida, M.R., Ruedell, C.M., Schwambach, J., Maraschin, F.S., and Fett-Neto, A.G. 2013. When stress and development go hand in hand: main hormonal controls of adventitious rooting in cuttings. Frontiers in Plant Science 4:133. doi:10.3389/fpls.2013.00133.

Dennis,P., Miller,A., and Hirsch,P. 2010. Are root exudates more important than other sources of rhizodeposits in structuring rhizosphere bacterial communities? FEMS Microbiology Ecology 72:313-327. doi:10.1111/j.1574-6941 2010.00860.

Díaz, K., Valiente, C., Martínez, M., Castillo, M., and Sanfuentes, E. 2009. Root-promoting rhizobacteria in Eucalyptus globulus cuttings. World Journal of Microbiology and Biotechnology 25:867-873. doi:10.1007/s11274-009-9961.

Dimkpa, C., Weinand, T., and Asch, F. 2009. Plant-rhizobacteria interactions alleviate abiotic stress conditions. Plant Cell and Environment 32:1682-1694. doi:10.1111/j.1365-3040.2009.02028.x.

Ferreira, A., Quecine, M., Teixeira, L.P., Oda, S., Azevedo, J., and Araujo, W. 2008. Diversity of endophytic bacteria from Eucalyptus species seeds and colonization of seedlings by Pantoea agglomerans. FEMS Microbiology Letters 287:814. doi:10.1111/j.1574-6968.2008.01258.x.

Geiss, G., Gutiérrez, L., and Bellini, C. 2009. Adventitious root formation: New insights and perspectives. Annual Plant Reviews 37:127-156. doi:10.1002/9781444310023.ch5.

Grattapaglia, D., and Kirst, M. 2008. Eucalyptus applied genomics: From gene sequences to breeding tools. New Phytologist 179:911-929. doi:10.1111/j.1469-8137.2008.02503.x. 
Gumiere, T., Ribeiro, C., Figueiredo, R., and Nogueira, E. 2014. Indole-3-acetic acid producing root-associated bacteria on growth of Brazil Pine (Araucaria angustifolia) and Slash Pine (Pinus elliottii). Antonie van Leeuwenhoek 105:663669. doi:10.1007/s10482-014-0120-9.

Humphreys, J.R., O’Reilly-Wapstra, J.M., Harbard, J.L., Davies, N.W., Griffin, A.R., Jordan, G.J., et al. 2008. Discrimination between seedlings of Eucalyptus globulus, E. nitens and their $\mathrm{F}_{1}$ hybrid using near-infrared reflectance spectroscopy and foliar oil content. Silvae Genetica 57:4-5.

INFOR. 2016. El sector forestal chileno 2016. Instituto Forestal (INFOR), Santiago, Chile. Available at http:// http://wef. infor.cl/sector_forestal/sectorforestal.php\#/10 (accessed January 2017).

Jopia, P., Urrutia, H., Sossa, K., and Nocker, A. 2011. Effect of PCR amplicon length on suppressing signals from membrane-compromised cells by propidium monoazide treatment. Journal Microbiological Methods 87:89-95. doi:10.1016/j.mimet.2011.07.016.

Karthikeyan, A., and Sakthivel, K. 2011. Efficacy of Azotobacter chroococcum in rooting and growth of Eucalyptus camaldulensis stem cuttings. Research Journal Microbiology 6:618-624. doi:10.3923/jm.2011.618.624.

Kim, B.C., Poo, H., Lee, K.H., Kim, N.M., Kwon, O., and Shin, K.S. 2012. Mucilaginibacter angelicae sp. nov., isolated from the rhizosphere of Angelica polymorpha Maxim. International Journal of Systematic and Evolutionary Microbiology 62:55-60. doi:10.1099/ijs.0.029728-0.

Madhaiyan, M., Poonguzhali, S., Lee, J.S., Senthikumar, M., Chul Lee, K., and Sundaram, S. 2010. Mucilaginibacter gossypii sp. nov. and Mucilaginibacter gossypiicola sp. nov., plant-growth-promoting bacteria isolated from cotton rhizosphere soils. Journal of Systematic and Evolutionary Microbiology 60:2451-2457. doi:10.1099/ijs.0.018713-0.

Madhibha, T., Murepa, R., Musokonyi, C., and Gapare, W. 2013. Genetic parameter estimates for interspecific eucalyptus hybrids and implications for hybrid breeding strategy. New Forest 44:63-84. doi:10.1007/s11056-011-9302-8.

Mafia, R.G., Alfenas, A.C., Maffia, L.A., Ferreira, E.M., Breda, D.H., and Siqueira, L. 2009. Microbiolization and interaction between growth promoting rhizobacteria and Eucalyptus clones. Revista Árvore 33:789-797.

Mafia, R., Alfenas, A., Maffia, L., Ferreira, E., and Siqueira, L. 2007. Effect of rhizobacteria on rooting and growth of Eucalyptus clones under different conditions of clonal propagation. Revista Árvore 31:813-821. doi:10.1590/S010067622007000500005.

Pardos, J.A. 2007. Perspectiva fisiológica en la producción y mejora de eucalipto (con énfasis en Eucalyptus globulus Labill). Boletín del CIDEU 3:7-55.

Probanza, A., García, J., Ruiz, M., Ramos, B., and Gutiérrez-Mañero, F. 2002 . Pinus pinea L. seedling growth and bacterial rhizosphere structure after inoculation with PGPR Bacillus (B. licheniformis CECT 5106 and B. pumilus CECT 5105). Applied Soil Ecology 20:75-84. doi:10.1016/S0929-1393(02)00007-0.

Puente, M., García, J., Pathauer, P., and Perticari, A. 2010. Inoculation with Azospirillum brasilense is a useful tool in Eucalyptus globulus management. American-Eurasian Journal of Agriculture and Environmental Sciences 8:124-130.

Qaisrani, M.M., Mirza, M.S., Zaheer, A., and Malik, A. 2014. Isolation and identification by 16S rRNA sequence analysis of Achromobacter, Azospirillum and Rhodococcus strains from the rhizosphere of maize and screening for the beneficial effect on plant growth. Pakistan Journal of Agricultural Sciences 51:91-99.

Raasch, L.D., Bonaldo, S.M., e de Oliveira, A.A.F. 2013. Bacillus subtilis: enraizamento e crescimento de miniestacas de eucalipto em Sinop, norte de Mato Grosso. Bioscience Journal 29:1446-1457.

Rezende, G.D., De Resende, M.D., and De Assis, T.S. 2014. Eucalyptus breeding for clonal forestry. p. 393-424. In Fenning, T. (ed.) Challenges and opportunities for the world's forests in the $21^{\text {st }}$ century. Springer, Dordrecht, The Netherlands.

Santoyo, G., Orozco-Mosqueda, M.C., and Govindappa, M. 2012. Mechanisms of biocontrol and plant growth promoting activity in soil bacterial species of Bacillus and Pseudomonas: A review. Biocontrol Science and Technology 22:855872. doi:10.1080/09583157.2012.694413.

Sotelo, M., and Monza, J. 2007. Micropropagation of Eucalyptus maidenii elite trees. Agrociencia 11:81-89.

Teixeira, D.A., Alfenas, A.C., Mafia, R.C., Ferreira, E.M., De Siqueira, L., Maffia, L.A., et al. 2007. Rhizobacterial promotion of eucalypt rooting and growth. Brazilian Journal of Microbiology 38:118-123. doi:10.1590/S151783822007000100025 .

Trotel-Aziz, P., Couderchet, M., Biagianti, S., and Aziz, A. 2008. Characterization of new bacterial biocontrol agents Acinetobacter, Bacillus, Pantoea and Pseudomonas spp. mediating grapevine resistance against Botrytis cinerea. Environmental and Experimental Botany 64:21-32. doi:10.1016/j.envexpbot.2007.12009.

Trueman, S., McMahon, T., and Bristow, T. 2013. Production of Eucalyptus cloeziana cuttings in response to stock plant temperature. Journal of Tropical Forest Science 25:60-69. 